\title{
Use of biogenic and abiotic elemental selenium nanospheres to sequester elemental mercury released from mercury contaminated museum specimens
}

\author{
J.W. Fellowes ${ }^{a}$,*, R.A.D. Pattrick ${ }^{a}$, D.I. Green ${ }^{a}$, A. Dent ${ }^{c}$, J.R. Lloyd $^{a}$, C.I. Pearce ${ }^{b}$ \\ a School of Earth, Atmospheric and Environmental Sciences, Williamson Building, University of Manchester, Oxford Road, Manchester M13 9PL, UK \\ b Pacific Northwest National Laboratory, Richland, WA, USA

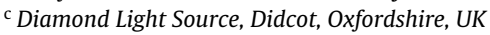

\section{A R T I C L E I N F O}

\section{Article history:}

Received 17 September 2010

Received in revised form 14 January 2011

Accepted 17 January 2011

Available online 26 January 2011

\section{Keywords:}

Mercury contamination

Botanical collections

Geobacter sulfurreducens

Selenium nanoparticles

\begin{abstract}
A B S T R A C T
Mercuric chloride solutions have historically been used as pesticides to prevent bacterial, fungal and insect degradation of herbarium specimens. The University of Manchester museum herbarium contains over a million specimens from numerous collections, many preserved using $\mathrm{HgCl}_{2}$ and its transformation to $\mathrm{Hg}_{\mathrm{v}}^{0}$ represents a health risk to herbarium staff. Elevated mercury concentrations in work areas $\left(\sim 1.7 \mu \mathrm{g} \mathrm{m}^{-3}\right)$ are below advised safe levels $\left(<25 \mu \mathrm{g} \mathrm{m}^{-3}\right)$ but up to $90 \mu \mathrm{g} \mathrm{m}^{-3}$ mercury vapour was measured in specimen boxes, representing a risk when accessing the samples. Mercury vapour release correlated strongly with temperature. Mercury salts were observed on botanical specimens at concentrations up to $2.85 \mathrm{wt} \%$ (bulk); XPS, SEM-EDS and XANES suggest the presence of residual $\mathrm{HgCl}_{2}$ as well as cubic $\mathrm{HgS}$ and $\mathrm{HgO}$. Bacterially derived, amorphous nanospheres of elemental selenium effectively sequestered the mercury vapour in the specimen boxes (up to $19 \mathrm{wt} \%$ ), and analysis demonstrated that the $\mathrm{Hg}_{\mathrm{v}}^{0}$ was oxidised by the selenium to form stable HgSe on the surface of the nanospheres. Biogenic $\mathrm{Se}^{0}$ can be used to reduce $\mathrm{Hg}_{\mathrm{v}}^{0}$ in long term, slow release environments.
\end{abstract}

(c) 2011 Elsevier B.V. All rights reserved.

\section{Introduction}

The preservation of botanical specimens in museums across the world has traditionally proven difficult. A wide range of organic and toxic metal biocides have been used to deter the onset of decay caused by bacteria, fungi, insects and rodents; the efficiency of these treatments can be seen by the excellent state of preservation in many specimens today. The use of mercury salt solutions in the preservation of botanical specimens goes back to 1687 , and continued in the UK up until the 1980s [1,2], ultimately giving way to organic pesticides including naphthalene, $\mathrm{p}$-dichlorobenzene, thymol, lindane and DDT [2,3]. The preparation of mercury bearing pesticide solutions is detailed by Briggs et al. [4] and a concentration of $30 \mathrm{~g} \mathrm{l}^{-1} \mathrm{HgCl}_{2}$ and $30 \mathrm{~g} \mathrm{l}^{-1}$ phenol dissolved into methylated spirits was used in the Cambridge University Herbarium, UK. The low rate of sublimation of $\mathrm{HgCl}_{2}$ and careful storage ensure that botanical specimens dating back hundreds of years still hold significant concentrations of $\mathrm{Hg}$; as $\mathrm{Hg}^{0}$, residual $\mathrm{HgCl}_{2}, \mathrm{HgS}$ and $2 \mathrm{HgO} \cdot \mathrm{HgS}$ [2,4-10]. Amalgamation of botanical collections into large herbaria, each having undocumented preservation techniques, has lead to inhomogeneous distribution of mercury contaminated specimens

\footnotetext{
* Corresponding author. Tel.: +44 161275 3800; fax: +44 1613069361.

E-mail address: Jonathan.Fellowes@postgrad.manchester.ac.uk (J.W. Fellowes).
}

within collections. Staining of sample mounting paper due to the formation of crystalline $\mathrm{Hg}$ phases has been used to identify the presence of $\mathrm{Hg}$-bearing compounds by fluorescence using UV irradiation [2].

Health risks associated with Hg-bearing botanical samples are not confined to dermal contact with contaminated specimens; Briggs et al. [4] report the evolution of $\mathrm{Hg}^{0}$ vapour leading to elevated local $\mathrm{Hg}$ concentrations of $25 \mu \mathrm{g} \mathrm{m}^{-3}$ at the Cambridge University Herbarium. Investigations in other herbaria indicate that this problem is widespread $[8,9]$. The concentration of $\mathrm{Hg}_{\mathrm{v}}^{0}$ is dependent on ambient temperature; Oyarzun et al. [8] show that the $\mathrm{Hg}$ vapour concentration in the MAF Herbarium, Spain rises from $404-727 \mathrm{ng} \mathrm{m}^{-3}$ in late winter $\left(23^{\circ} \mathrm{C}\right)$ to $748-7797 \mathrm{ng} \mathrm{m}^{-3}$ in early summer $\left(31^{\circ} \mathrm{C}\right)$. Oyarzun et al. [8] also show that in a well insulated herbarium such as the relatively modern MA Herbarium, Spain, $\mathrm{Hg}_{\mathrm{v}}^{0}$ concentrations exceeded $40 \mu \mathrm{g} \mathrm{m}^{-3}$.

Regulatory standards for workplace exposure limits have been summarised by Baughman [11], with guideline exposure limits varying between $25 \mu \mathrm{g} \mathrm{m}^{-3}$ and $100 \mu \mathrm{g} \mathrm{m}^{-3} \mathrm{Hg}$. It is also noted that children are much more susceptible to $\mathrm{Hg}$ toxicity than adults, which is of concern for public access museums.

The transformation mechanism of the relatively stable $\mathrm{HgCl}_{2}$ into $\mathrm{Hg}^{0}$ is not well understood. Oyarzun et al. [8] surmised that microbial enzymatic reduction of $\mathrm{Hg}^{2+}$ to $\mathrm{Hg}_{\mathrm{v}}^{0}$ as part of a $\mathrm{Hg}$ detoxification mechanism may be responsible, and work by Roane and 
Snelling [12] has identified bacteria isolated from museum specimens that display a high $\mathrm{Hg}^{2+}$ tolerance (in excess of $10 \mathrm{mg} \mathrm{l}^{-1}$ ), which may also be used as a possible remediation strategy. Complicating this process, however, is the presence of a range of other pesticides often found alongside $\mathrm{Hg}$.

Briggs et al. [4] and Oyarzun et al. [8] both report that an increase in ventilation significantly drops the $\mathrm{Hg}_{\mathrm{v}}^{0}$ content of the air. There are circumstances where increasing ventilation cannot be considered due to climate, expense or positioning of the herbarium within buildings, and so an alternative method for decreasing the $\mathrm{Hg}$ content of herbarium and museum specimens must be identified.

Johnson et al. [13] studied the capture of $\mathrm{Hg}_{\mathrm{v}}^{0}$ by nanoscale sorbents, and note that elemental $\alpha$-Se nanoparticles sequester $\mathrm{Hg}$ more efficiently than many commercially available sorbents. Se nanoparticles can be produced biogenically by bacterial reduction of soluble Se oxyanions. Se pollution, in the form of the oxyanions selenate $\left[\mathrm{SeO}_{4}{ }^{2-}\right]$ and selenite $\left[\mathrm{SeO}_{3}{ }^{2-}\right]$, is associated with waste materials from a broad spectrum of anthropogenic operations, including mining, agricultural, petrochemical, and industrial manufacturing operations [14]. Water-soluble forms of selenium can be microbiologically reduced to elemental selenium nanoparticles, which are less bioavailable and generally less toxic than other selenium species. The elemental selenium nanoparticles can potentially be separated from the aqueous waste stream [15]. The biologically recovered selenium nanoparticles can then be used in subsequent applications, such as the sequestration of elemental mercury released from mercury contaminated museum specimens, to offset the cost of the biological treatment [16]. This highlights how biomineralisation approaches can be applied to convert metal-containing wastes into new nanomaterials for environmental protection [17].

This research reveals the nature and extent of $\mathrm{Hg}$ contamination associated with museum specimens and measurement of $\mathrm{Hg}$ content of airspaces at the herbarium of the Manchester museum (The University of Manchester, UK), which has a botanical collection approaching a million specimens from all over the world, representing collections spanning hundreds of years. The collection is subdivided into British and European collections, as well as several smaller collections. The level of $\mathrm{Hg}$ contamination is inhomogeneous and poorly documented. This work also investigates the use of Se bionanominerals, which display an increased stability in comparison with their chemically synthesised counterparts
$[14,18,19]$ for the capture of $\mathrm{Hg}_{\mathrm{V}}^{0}$ released from specimens within herbaria.

\section{Materials and methods}

All chemicals used were of analytical grade and obtained from Sigma-Aldrich (UK).

\subsection{Determination of herbarium air $H g_{v}^{0}$ concentration}

The $\mathrm{Hg}$ content of the herbarium air was determined using a portable mercury vapour indicator (MVI, Shawcity, Faringdon, UK). $\mathrm{The} \mathrm{Hg}_{\mathrm{v}}^{0}$ concentration of the air was determined around the central workspaces of the herbarium and in sample boxes from a number of collections. The boxes analysed were chosen at random and were analysed immediately for $\mathrm{Hg}_{\mathrm{v}}^{0}$ concentration.

\subsection{Sampling}

The museum's herbarium specimens are mounted onto A3 sized cardboard sheets and stored in fabric lined cardboard boxes on shelves within the herbarium, as shown in Fig. 1.

Samples from the British and European collections were analysed for $\mathrm{Hg}$ concentration and oxidation state. Due to the irreplaceable nature of the specimens, milligram sized samples were taken and non-destructive analysis techniques (X-ray diffraction (XRD), X-ray photoelectron spectroscopy (XPS), scanning electron microscopy (SEM) coupled to energy dispersive spectroscopy (EDS) and X-ray absorption spectroscopy (XAS)) were used prior to chemical dissolution to determine bulk $\mathrm{Hg}$ values. Samples include leaf segments, mounting paper and plant sample debris (Table 1).

\subsection{Mercury sequestration experiments}

The $\mathrm{Hg}$ absorption capacity of dry powders of both biogenic and abiotic $\mathrm{Se}^{0}$ was tested. Biogenic red elemental $\alpha$-Se was formed by the reduction of $\mathrm{Na}_{2} \mathrm{SeO}_{3}$ by Geobacter sulfurreducens coupled to the oxidation of $\mathrm{H}_{2}$. G. sulfurreducens (ATCC 51573) was obtained from the Geomicrobiology Laboratory (University of Manchester) collection and grown to late log phase in modified freshwater medium amended with sodium acetate and fumarate as the electron donor and acceptor, respectively [20]. Cells

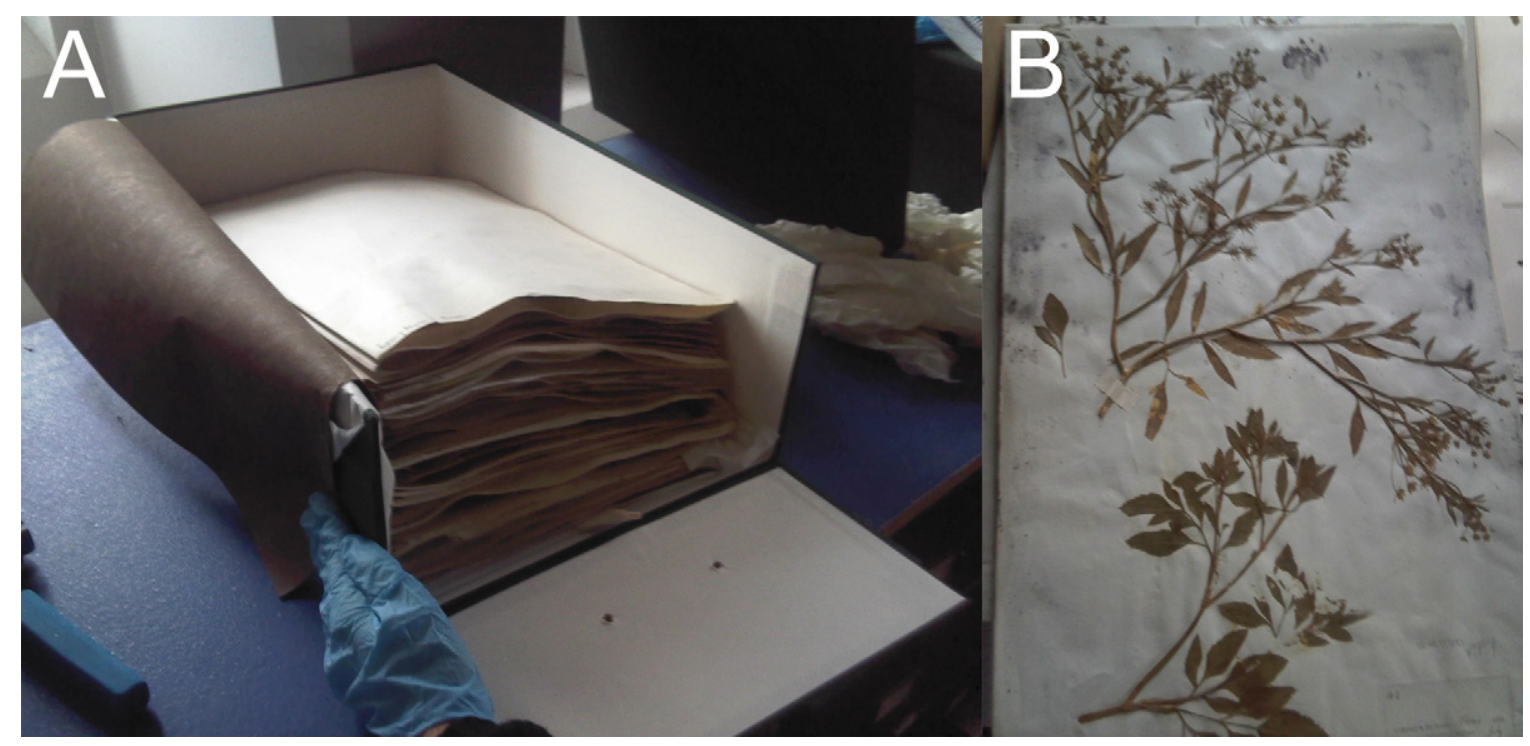

Fig. 1. Stacks of herbarium samples in containing boxes (left) and a typical herbarium specimen mounted on A3 paper with dark staining visible towards the top (right). 
Table 1

Samples for analysis from the herbarium of the Manchester museum. Hg concentrations were determined by acid digestion and ICP-MS.

\begin{tabular}{|c|c|c|}
\hline Sample number & Sample description & $\begin{array}{l}\text { Hg concentrations } \\
\text { (wt\%) }\end{array}$ \\
\hline \multicolumn{3}{|c|}{ Box 5719 Rubus 106} \\
\hline 1 & $\begin{array}{l}\text { Plant samples/debris, } \\
\text { collected from crease of } \\
\text { sample paper }\end{array}$ & 0.24 \\
\hline 2 & $\begin{array}{l}\text { Sample of paper with grey } \\
\text { residue (EM322125) }\end{array}$ & $\mathrm{N} / \mathrm{A}$ \\
\hline 3 & $\begin{array}{l}\text { Plant samples/debris, } \\
\text { collected from crease of } \\
\text { sample paper folder } \\
\text { Rubus incubatus VC58 } \\
\text { (+59 in part) }\end{array}$ & 0.22 \\
\hline 4 & $\begin{array}{l}\text { Material/dust collected } \\
\text { from lining of box }\end{array}$ & 2.85 \\
\hline \multicolumn{3}{|c|}{ Box Scorzonera 135.18.1 } \\
\hline 5 & $\begin{array}{l}\text { Biscuit beetle, Stegobium } \\
\text { paniceum }\end{array}$ & 0.08 \\
\hline 6 & $\begin{array}{l}\text { Plant samples/debris, } \\
\text { collected from crease of } \\
\text { sample paper (folder } \\
\text { Asteraceae VC } 58,59,60 \text { ) }\end{array}$ & 0.04 \\
\hline \multicolumn{3}{|l|}{ Box \#6200 } \\
\hline 7 & $\begin{array}{l}\text { EM35411, Eucalyptus leaf } \\
\text { sample, labelled as } \\
\text { 'poisoned' }\end{array}$ & 0.08 \\
\hline 8 & $\begin{array}{l}\text { Sample of paper [from } \\
\text { 545(80)] from Hewett } \\
\text { Cottrell Watson Carum } \\
\text { sp. Folder from Azores } \\
1842\end{array}$ & $\mathrm{~N} / \mathrm{A}$ \\
\hline 9 & Sample of stem from above & 0.07 \\
\hline
\end{tabular}

were harvested, washed and re-suspended in $20 \mathrm{mmoll}^{-1} 3-(\mathrm{N}-$ morpholino)propanesulfonic acid (MOPS) buffer at $\mathrm{pH}$ 7. Aliquots of the cell suspension were used to inoculate sterile, anaerobic solutions (final $\mathrm{OD}_{600} \sim 0.2$ ) of $1 \mathrm{mmoll}^{-1} \mathrm{Na}_{2} \mathrm{SeO}_{3}$ in $20 \mathrm{mmoll}^{-1}$ MOPS amended with $2 \mu \mathrm{moll}^{-1}$ of the electron shuttling compound anthraquinone-2,6-disulfonate (AQDS). The headspaces of the bottles were replaced with $\mathrm{H}_{2}$ as an electron donor. Cultures were incubated at $30^{\circ} \mathrm{C}$ and red $\mathrm{Se}^{0}$ was precipitated. To produce abiotic $\mathrm{Se}^{0}$, a solution containing $1 \mathrm{mmoll}^{-1} \mathrm{Na}_{2} \mathrm{SeO}_{3}$ and $4 \mathrm{mmoll}^{-1}$ glutathione (reduced) was titrated against a $1 \mathrm{~N} \mathrm{NaOH}$ solution until the formation of red elemental Se was observed [13]. For the sequestration experiments, biogenic and abiotic red $\mathrm{Se}^{0}$ suspensions $(5 \mathrm{ml})$ were filtered through $0.22 \mu \mathrm{m}$ polycarbonate micropore filters, washed with deionised $\mathrm{H}_{2} \mathrm{O}(5 \mathrm{ml})$ and allowed to air dry.

\subsubsection{Open system experiments}

The $\mathrm{Se}^{0}$-containing membrane filters were tested to determine the rate at which $\mathrm{Hg}^{0}$ could be sequestered from an $\mathrm{Hg}^{0}$-containing $\mathrm{N}_{2}$ gas flow. The source of $\mathrm{Hg}_{\mathrm{v}}^{0}$ in these experiments were solutions containing $10 \mathrm{ppm} \mathrm{HgCl}_{2}$ and $100 \mathrm{ppm} \mathrm{SnCl}_{2}$ [21]. $\mathrm{N}_{2}$ was bubbled through the $\mathrm{HgCl}_{2} / \mathrm{SnCl}_{2}$ solutions at a varied flow rate (10-50 $\mathrm{ml} \mathrm{min}^{-1}$ ) and into 11 vessels containing the $\mathrm{Se}^{0}$ membrane filters. Effluent was passed through an acidified $\mathrm{KMnO}_{4}$ solution prior to release under a fume hood [22]. The filters were exposed to the $\mathrm{Hg}^{0}$-laden $\mathrm{N}_{2}$ flow for $3 \mathrm{~h}$ and stored at $-80^{\circ} \mathrm{C}$ prior to acid digestion and $\mathrm{Hg}$ determination using ICP-MS.

Real-time determination of the effect of Se-bearing membrane filters on a metered $\mathrm{Hg}$-laden gas flow was analysed via a modified Cetac M6000A Cold Vapour Atomic Absorption Spectrometer (CVAAS) mercury analyser. Modifications to this equipment involved the removal of the auto sampling stage and inline attachment of $\mathrm{Se}^{0}$-bearing membrane filters, altering analyses from aqueous, single point $\mathrm{Hg}$ determination to a real-time analysis of $\mathrm{Hg}$ concentration in the gas phase.

\subsubsection{Sealed environment experiments}

The ability of the $\mathrm{Se}^{0}$-containing membrane filters to sequester $\mathrm{Hg}_{\mathrm{v}}^{0}$ was assessed under idealised laboratory conditions. Se ${ }^{0}$ laden membrane filters were inserted into air tight 11 jars for 1 week at constant temperature $\left(19^{\circ} \mathrm{C}\right) . \mathrm{HgCl}_{2} / \mathrm{SnCl}_{2}$ solutions served as the $\mathrm{Hg}_{\mathrm{v}}^{0}$ source for these experiments. $\mathrm{HgCl}_{2}$ concentrations ranged from $10 \mathrm{ppb}$ to $10 \mathrm{ppm}$ and $\mathrm{SnCl}_{2}$ concentrations were kept in the ratio 1:100 $\mathrm{Hg}: \mathrm{Sn}$. After 1 week, $\mathrm{Se}^{0}$ membrane filters were removed from the sealed jars and stored at $-80^{\circ} \mathrm{C}$ prior to acid digestion and $\mathrm{Hg}$ determination using ICP-MS.

\subsubsection{In situ experiments}

Biogenic $\mathrm{Se}^{0}$-containing membrane filters were inserted into herbarium specimen boxes known to contain significant $\mathrm{Hg}_{\mathrm{V}}^{0}$ concentrations $\left(>25 \mu \mathrm{g} / \mathrm{m}^{3}\right)$. The samples were left for four weeks, during which the time ambient temperature rose from $19^{\circ} \mathrm{C}$ to $24^{\circ} \mathrm{C}$ due to weather conditions. Following collection, samples were stored at $-80^{\circ} \mathrm{C}$ until acid digestion for $\mathrm{Hg}$ determination.

\subsection{Hg-species characterisation}

Samples described in Table 1 and $\mathrm{Se}^{0}$-containing membrane filters from the mercury sequestration experiments were analysed by SEM using a Philips XL30 FEG-ESEM with elemental analysis by EDAX Gemini EDS. All samples were mounted onto adhesive Ccoated $\mathrm{Al}$ stubs to remove interference in Se determination caused by overlapping $\mathrm{Al}$ emission peaks. XRD of mounting paper samples (Table 1) was carried out on a Bruker D8 Advance with a $\mathrm{Cu}-\mathrm{K} \alpha$ source. Spectra were compared to samples published by the International Centre for Diffraction Data (ICDD). XPS was carried out on sample 7 (Table 1 ) with a Kratos AXIS Ultra using monochromated $\mathrm{Al} \mathrm{K \alpha}$ radiation and a wide scan pass energy of $80 \mathrm{eV}$ with narrow scans recorded at $20 \mathrm{eV}$ pass energy for greater chemical state resolution. The intense $C$ 1s peak was used to normalise the energy of the spectra.

XAS was performed on samples described in Table 1 and $\mathrm{Se}^{0}$-containing membrane filters at the Diamond Light Source, Oxfordshire, UK, on the core XAS beamline B18 where samples were analysed at the $\mathrm{Hg} L_{3}$ absorption edge at $12.287 \mathrm{keV}$. HgS standards were used for absorption edge energy normalisation. Sample identification was via determination of inflection point difference (IPD) as described by Huggins et al. [23].

Acid digestion using aqua regia $(1 \mathrm{ml})$ with a molar ratio 1:4 $\mathrm{HCl}: \mathrm{HNO}_{3}$ was used to determine the concentration of $\mathrm{Hg}$ in all sample materials. Excess $\mathrm{HNO}_{3}$ was used to encourage formation of $\mathrm{Hg}^{2+}$ cations to decrease losses due to volatility. Samples were run on an Agilent 7500cx ICP-MS, with quoted Hg detection down of 10 ppt. A $10 \mathrm{ppm}$ Au solution was run concurrently to inhibit $\mathrm{Hg}$ retention. To ensure complete recovery of $\mathrm{Hg}$, a $1 \mathrm{ml} \mathrm{HF}-\mathrm{HCl}-\mathrm{HNO}_{3}$ digestion ( $5: 1: 4)$ was used on any remaining material. The HF was neutralised using a $4 \mathrm{wt} \%$ solution of $\mathrm{H}_{3} \mathrm{BO}_{3}$. Owing to the necessary high dissolved solid content, these samples were analysed using a Perkin-Elmer Optima 5300 dual view ICP-AES.

\section{Results and discussion}

\subsection{Determination of herbarium air $\mathrm{Hg}_{v}^{0}$ concentration}

The $\mathrm{Hg}_{\mathrm{v}}^{0}$ concentration of air around the work area was $1.7 \mu \mathrm{g} \mathrm{m}^{-3}$ at $21^{\circ} \mathrm{C}$, which did not significantly alter throughout the herbarium. These results are similar to those observed in previous studies by Oyarzun et al. [8] and Kataeva et al. [9], which 


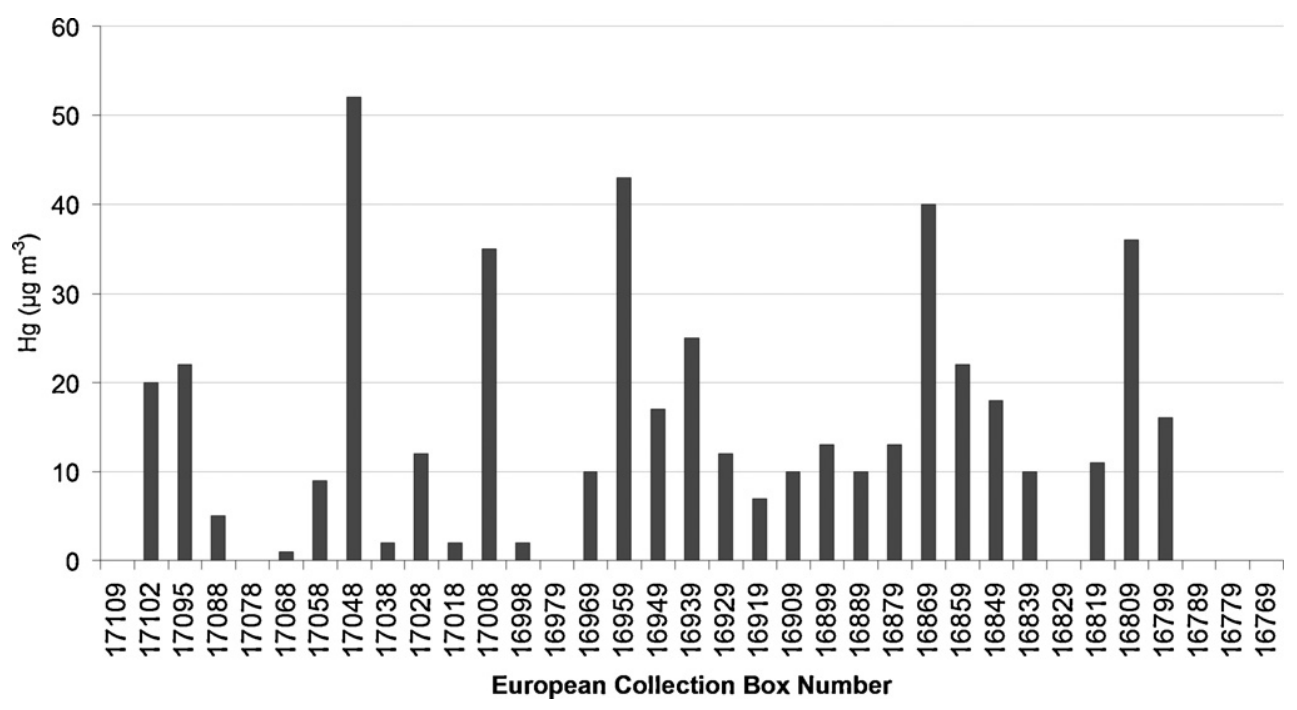

Fig. 2. $\mathrm{Hg}_{\mathrm{v}}^{0}$ concentrations within herbarium specimen boxes.

recorded readings of up to $0.7 \mu \mathrm{g} \mathrm{m}^{-3}$ and $1.1 \mu \mathrm{g} \mathrm{m} \mathrm{m}^{-3}$ under similar conditions $\left(\sim 21-23^{\circ} \mathrm{C}\right)$.

The $\mathrm{Hg}_{\mathrm{v}}^{0}$ concentration within the specimen boxes was determined for 70 boxes from 5 collections, of which 55 came from either the British or European collections. The $\mathrm{Hg}_{\mathrm{v}}^{0}$ concentrations were highly variable with the highest concentrations in the European collection with $\mathrm{Hg}_{\mathrm{v}}^{0}$ ranging from below detection limits up to $52 \mu \mathrm{g} \mathrm{m}^{-3}$, with 5 boxes tested recording $>25 \mu \mathrm{g} \mathrm{m}^{-3}$ (Fig. 2). The British collection was largely free of significant $\mathrm{Hg}$-contamination; however the $\mathrm{Hg}_{\mathrm{v}}^{0}$ readings for the Rubus sp. type samples box were in excess of $40 \mu \mathrm{g} \mathrm{m}^{-3}$ (data not shown).

High $\mathrm{Hg}_{\mathrm{v}}^{0}$ concentrations were not observed outside of the specimen boxes prior to opening, indicating that the boxes inhibit the release of $\mathrm{Hg}$ into the working environment.

\subsection{Characterisation of museum Hg-contaminated specimens}

\subsubsection{Electron microscopy and X-ray diffraction}

Fig. 3A shows representative SEM images of samples collected from specimen boxes containing grains of sample debris (sample 4). EDS revealed that most of the samples examined did not have significant quantities of $\mathrm{Hg}$. However, analysis of one particular grain (Fig. 3B and C), showed $\sim 1 \mu \mathrm{m}$ particles composed of $\sim 87 \mathrm{wt} \% \mathrm{Hg}$ with the counter ions $\mathrm{S}^{2-}$ and $\mathrm{Cl}^{-}$. The $\mathrm{S}$ component could not be quantified due to the overlap of the $\mathrm{Hg} \mathrm{M}$ and $\mathrm{S} \mathrm{K}$ emission lines, but the $\mathrm{Hg}$ wt\% observed is similar to that expected from pure $\mathrm{HgS}$ (86 wt\% as opposed to $74 \mathrm{wt} \%$ and $93 \mathrm{wt} \% \mathrm{Hg}$ in $\mathrm{HgCl}_{2}$ and $\mathrm{HgO}$, respectively).

Samples of the A3 specimen mounting card (samples 2 and 8) were analysed by XRD (Fig. 4), indicating the presence of crystalline $\mathrm{Hg}$ phases. Sample 2 displayed peaks corresponding to unaltered $\mathrm{HgCl}_{2}$ (ICDD PDF No. 00-026-0315) whilst sample 8 displayed a reflection at $26.4^{\circ} 2 \theta$, suggesting crystalline metacinnabar (ICDD PDF No. 00-006-0261). Hawks et al. [6] and Purewal et al. [2] have previously observed crystalline $\mathrm{HgO}, \mathrm{HgS}$ and $\mathrm{HgCl}_{2}$ phases on the mounting card.

\subsubsection{XPS and XAS analysis}

XPS analysis was used to identify the chemical forms of $\mathrm{Hg}$ present on the sample surface. Fig. 5 shows XPS spectra obtained from a Eucalyptus sp. leaf (sample 7) historically treated with $\mathrm{Hg}$-based pesticides. XPS analysis showed that $\mathrm{Hg}$ was inhomogeneously distributed, with some areas falling below detection limits and others up to $1100 \mathrm{ppm}$. For the high $\mathrm{Hg}$-containing areas, the
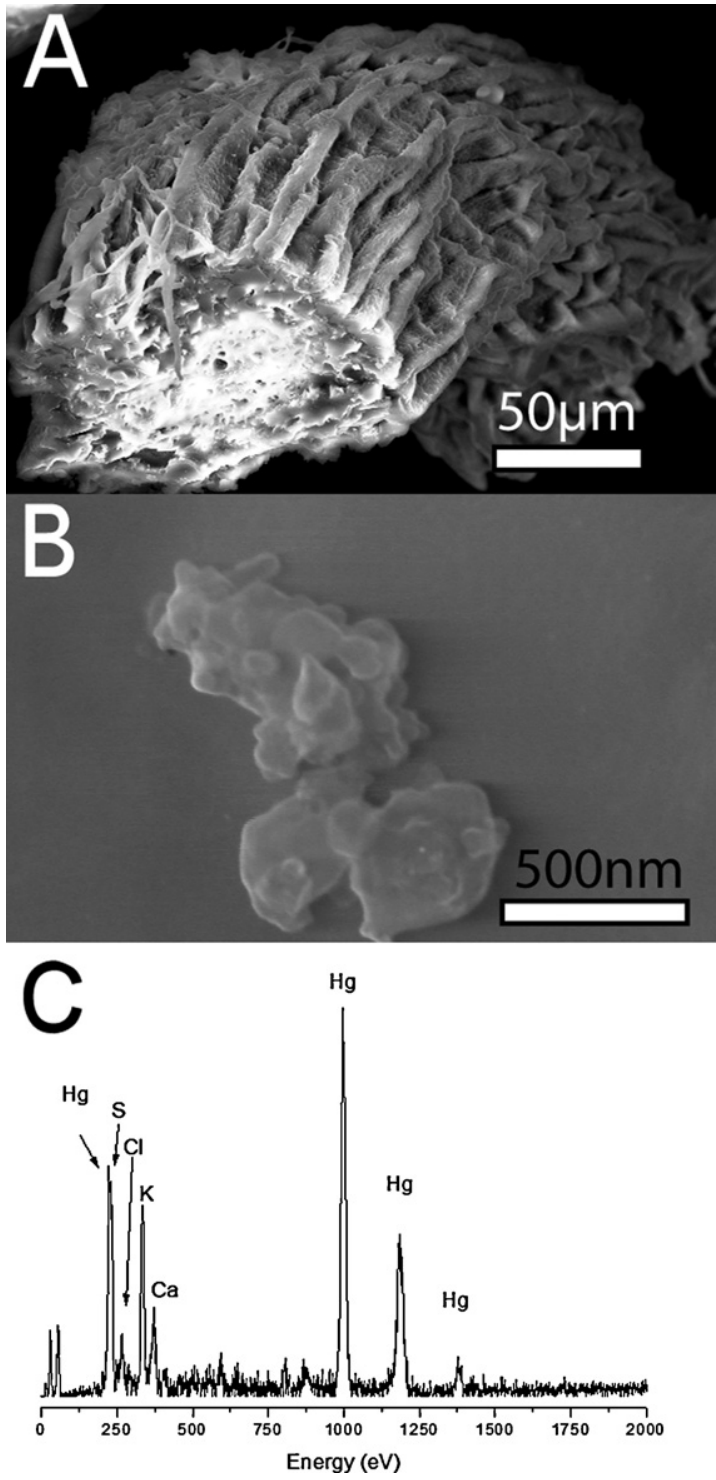

Fig. 3. SEM and EDS analysis of sample 4 (box 5719 Rubus sp.). (A) View of typical debris collected from within museum boxes; (B) and (C) SEM and EDS analysis showing irregular Hg-rich particles. 


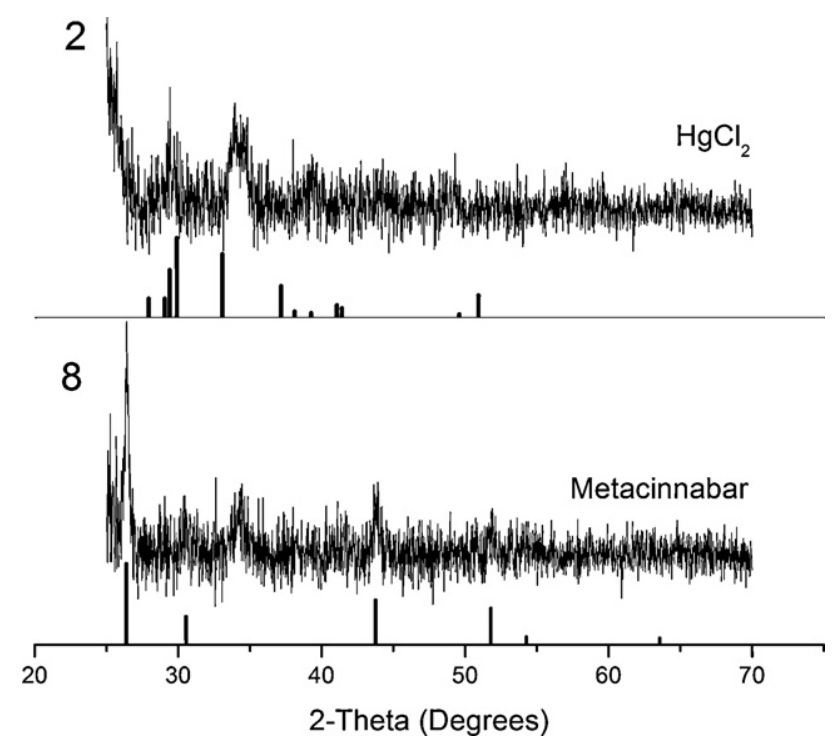

Fig. 4. XRD data from analysis of samples 2 and 8 (mounting card). (A) Indicating remnant $\mathrm{HgCl}_{2}$ and (B) diffraction peaks suggesting metacinnabar.

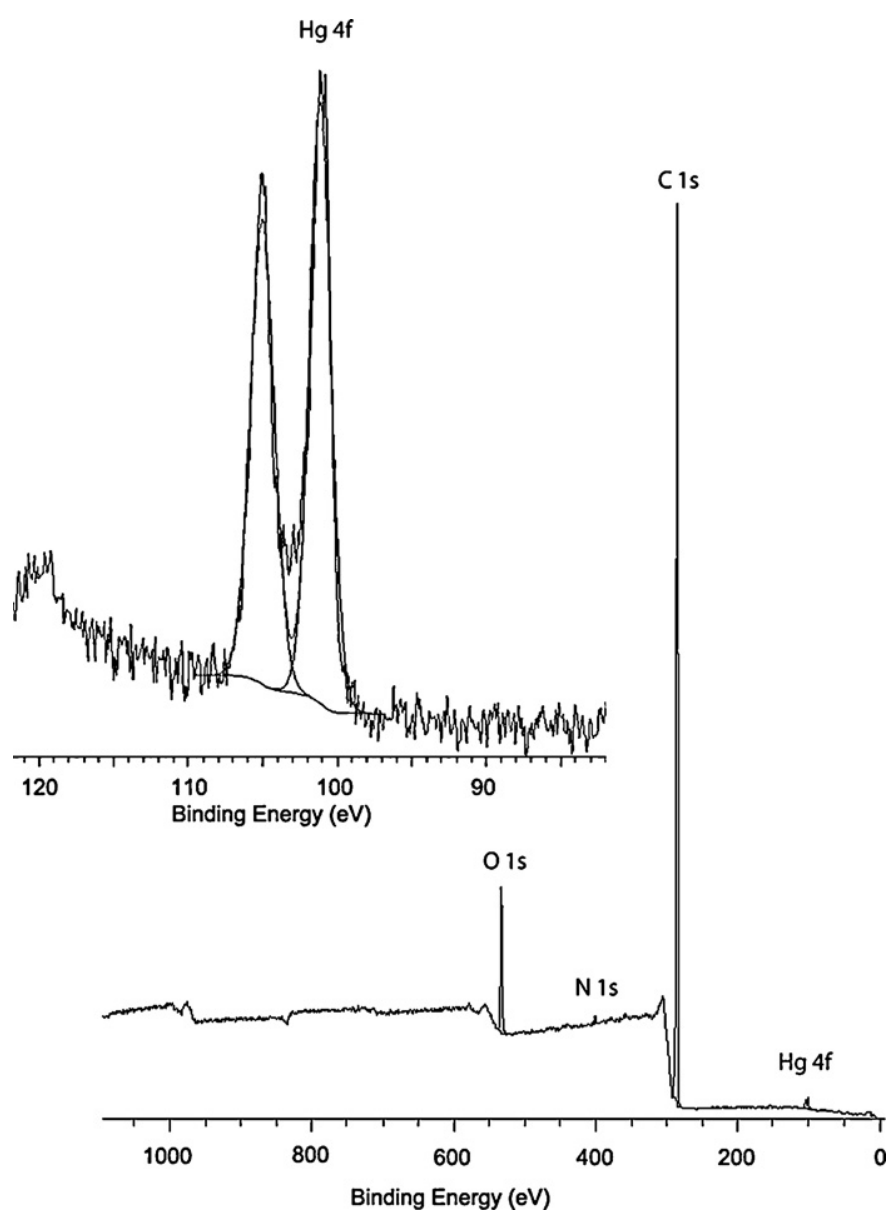

Fig. 5. XPS wide scan and inset, narrow scan spectra of Eucalyptus sp. leaf. Peaks correlating to $\mathrm{Hg}, \mathrm{C}, \mathrm{N}$ and $\mathrm{O}$ are all clearly discernable. Hg concentration determined to be $\sim 1100 \mathrm{ppm}$.

binding energy for the $\mathrm{Hg} 4 \mathrm{f}$ emission was $101 \mathrm{eV}$. Comparison with published standards indicates that the $\mathrm{Hg}$ could be present as $\mathrm{HgS}$, $\mathrm{HgCl}_{2}, \mathrm{HgO}$ or as an organo-mercury compound, but precludes the presence of $\mathrm{Hg}^{0}$ [24].
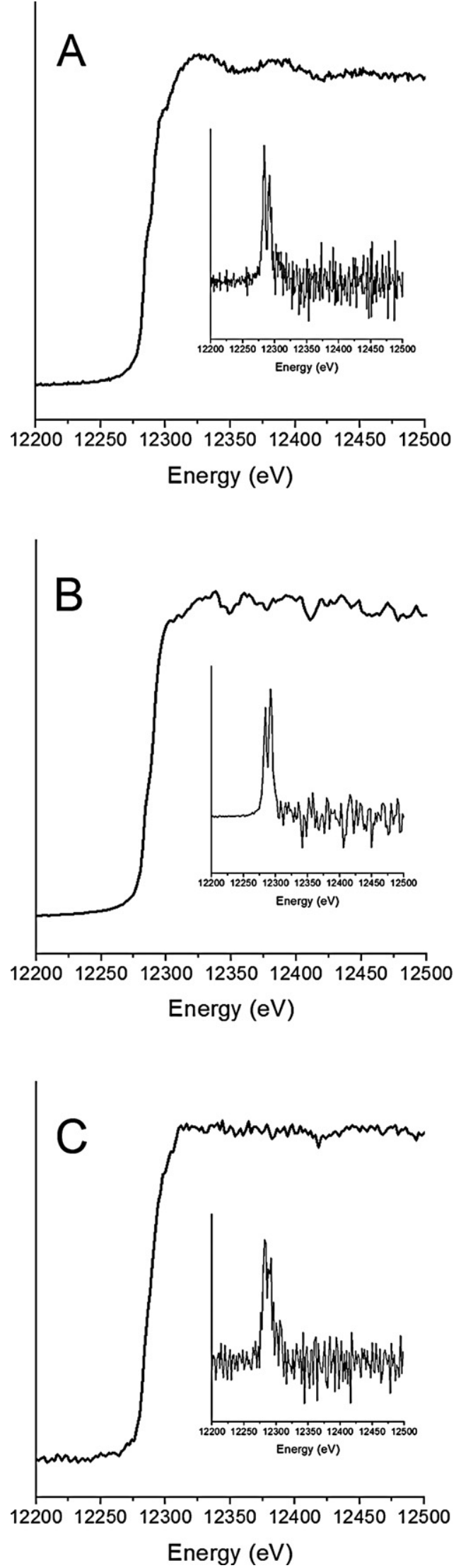

Fig. 6. XANES $\mathrm{Hg} L_{3}$ absorption edge spectra obtained from (A) Eucalyptus sp. leaf; (B) box dust (sample 4) and (C) Se-laden polycarbonate membrane filter exposed to $\mathrm{Hg}_{\mathrm{v}}^{0}$. Inset: 1 st derivatives of the XANES spectra. 
The XANES spectrum derived from the Eucalyptus sp. leaf is presented in Fig. 6A, with the 1st derivative of the XANES spectrum inset. An IPD value of $7.88 \mathrm{eV}$ was recorded for the first derivation, consistent with published $\mathrm{HgS}$ species [25]. Linear combination fitting of published $\mathrm{HgS}$ standards $[23,25,26]$ suggests the XANES profile is consistent with metacinnabar, concordant with XRD findings. An IPD value of $7.89 \mathrm{eV}$ was derived from the XANES analysis (Fig. 6B, inset) of the Hg-rich dust (sample 4), and is concordant with the EDS indicating the presence of a dominant $\mathrm{HgS}$ phase. The presence of multiple peaks in the 1st derivation of all XANES spectra obtained shows no $\mathrm{Hg}^{0}$ is present in these samples.

\subsubsection{Acid digestion of specimens in Table 1}

Total extraction of $\mathrm{Hg}$ from the museum specimens was used to determine absolute $\mathrm{Hg}$ concentrations. The results of the sequential acid extractions using aqua regia and $\mathrm{HF}$-aqua regia showed that $\mathrm{Hg}$ concentration in the specimens varied greatly (Table 1). Interestingly, the digests show that the Eucalyptus sp. leaf and plant stem (samples 7 and 9) do not contain significant concentrations of $\mathrm{Hg}$ ( 0.08 and $0.07 \mathrm{wt} \%$ ). Dust and debris collected from two of the specimen wrapping sheets (samples 1 and 3 ) show Hg concentrations of $\sim 0.2 \mathrm{wt} \%$, but debris collected from the box containing the specimens (sample 4) had a $\mathrm{Hg}$ concentration of $2.85 \mathrm{wt} \%$, over an order of magnitude larger. These results highlight the heterogeneity of $\mathrm{Hg}$ contamination within the specimens and may relate to varying pesticide coating practices. Hg contamination was found in all samples.

\subsection{Mercury sequestration experiments}

\subsubsection{Selenium nanoparticle and filter characterisation}

Selenium impregnated membrane filters were characterised prior to use in laboratory experiments by ICP-AES/-MS, SEM with EDS and particle sizing. Total acid digests showed that membrane filters were loaded with $500-600 \mu \mathrm{g}$ of Se per filter for both abiotic and biogenic Se nanoparticles. SEM analyses of the loaded membranes prior to experimentation show smooth, spherical particles approximately $100-200 \mathrm{~nm}$ in diameter (Fig. 7A). EDS analyses of the Se phases (Fig. 7Di) show a dominant Se L edge peak at $1.4 \mathrm{eV}$ along with smaller $\mathrm{C}$ and $\mathrm{O}$ emissions from the filter material, indicating a pure Se phase. Size distribution information was obtained (Fig. 8E) and was concordant with SEM analyses show particles ranging from 40 to $700 \mathrm{~nm}$, similar to that as reported by Johnson et al. [13]. Size distribution information was used to calculate surface area assuming spherical particles; abiotic $\mathrm{Se}^{0}$ had a surface area of $11.64 \mathrm{~m}^{2} \mathrm{~g}^{-1}$ and biogenic $\mathrm{Se}^{0} 9.64 \mathrm{~m}^{2} \mathrm{~g}^{-1}$ equating to $5.8-7.0 \times 10^{-3} \mathrm{~m}^{2}$ and $4.8-5.8 \times 10^{-3} \mathrm{~m}^{2}$ per filter, respectively.

\subsubsection{Open system experiments}

Biogenic $\mathrm{Se}^{0}$-containing membrane filters were assessed using the modified CVAAS to follow the evolution of $\mathrm{Hg}_{\mathrm{v}}^{0}$ from a $10 \mathrm{ppb}$ $\mathrm{Hg}^{2+} / \mathrm{Sn}^{2+}$ solution and to determine the effect of Se on the $\mathrm{Hg}_{\mathrm{v}}^{0}$ release (Fig. 9). Evolution of $\mathrm{Hg}_{\mathrm{v}}^{0}$ at a flow rate of $50 \mathrm{ml} \mathrm{min}^{-1}$ shows an initial spike corresponding to release of $\mathrm{Hg}_{\mathrm{v}}^{0}$, followed by an exponential decay over time $\left(r^{2}=0.98\right)$. The addition of biogenic $\mathrm{Se}^{0}$ to the inline membrane filter drastically decreased initial $\mathrm{Hg}_{\mathrm{v}}^{0}$

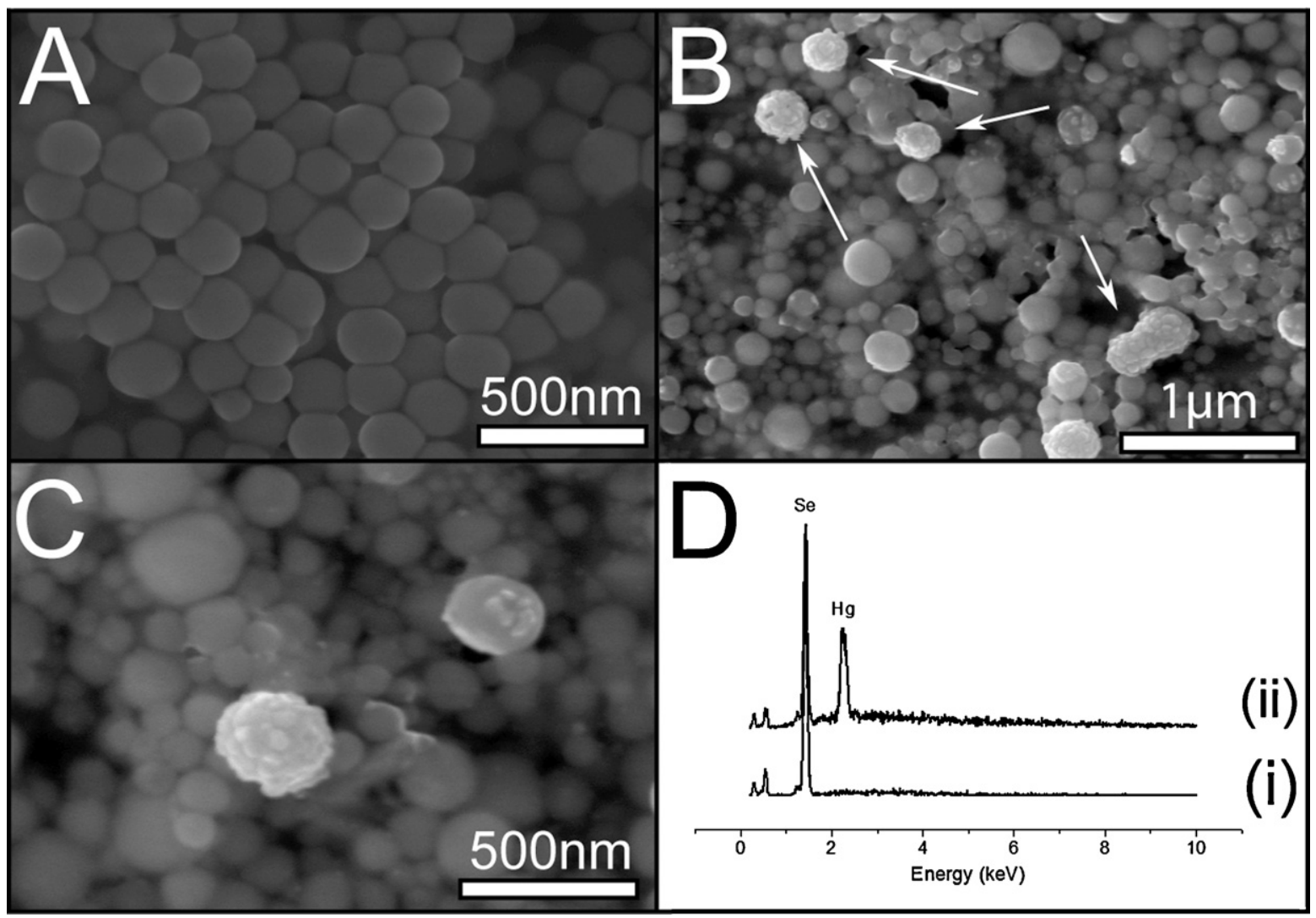

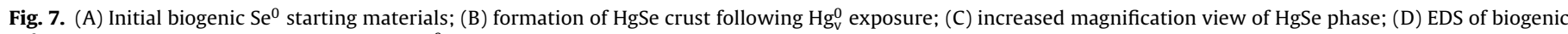
$\mathrm{Se}^{0}$ before (i) and following (ii) exposure to $\mathrm{Hg}_{\mathrm{v}}^{0}$. 

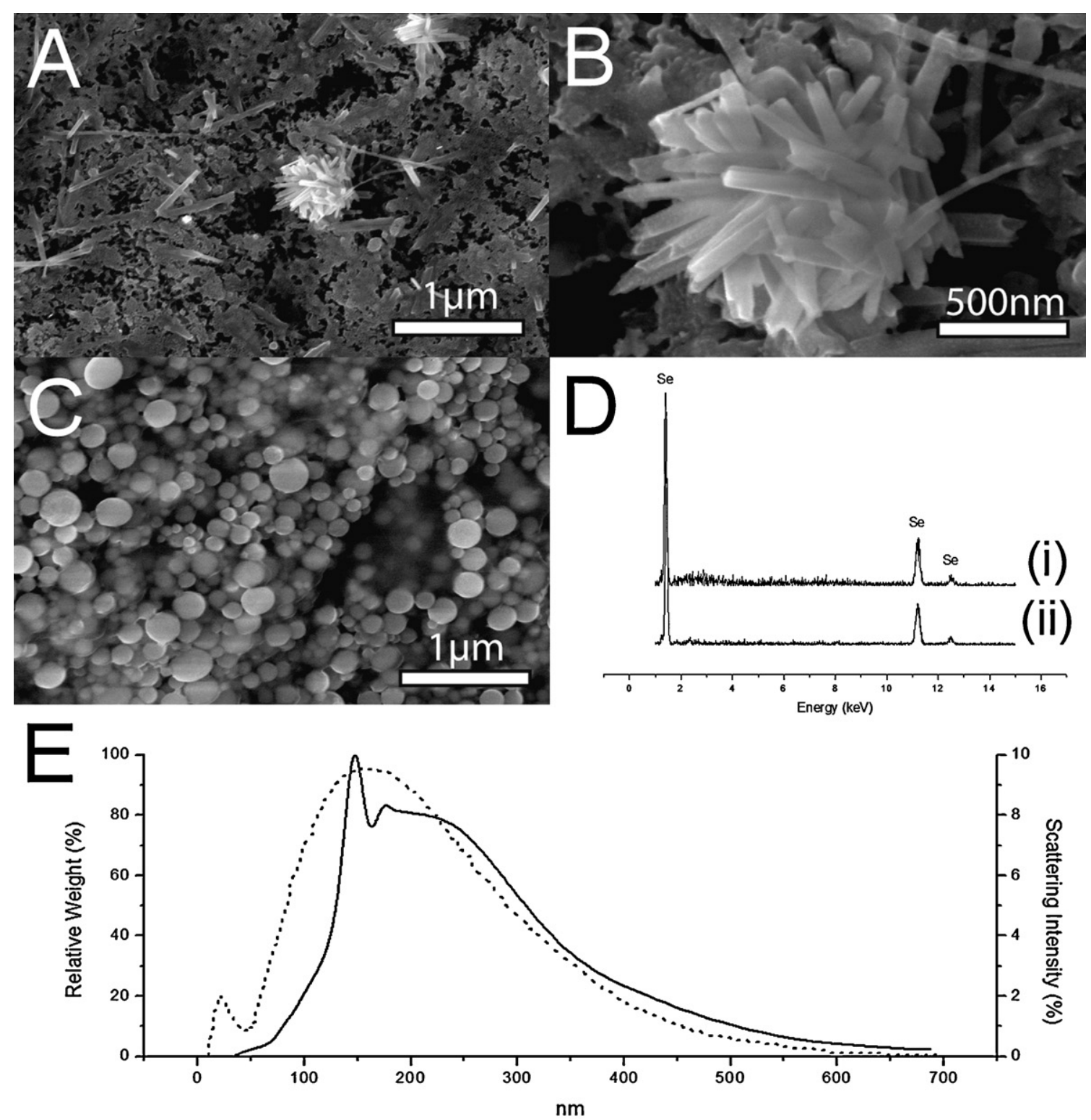

(100)

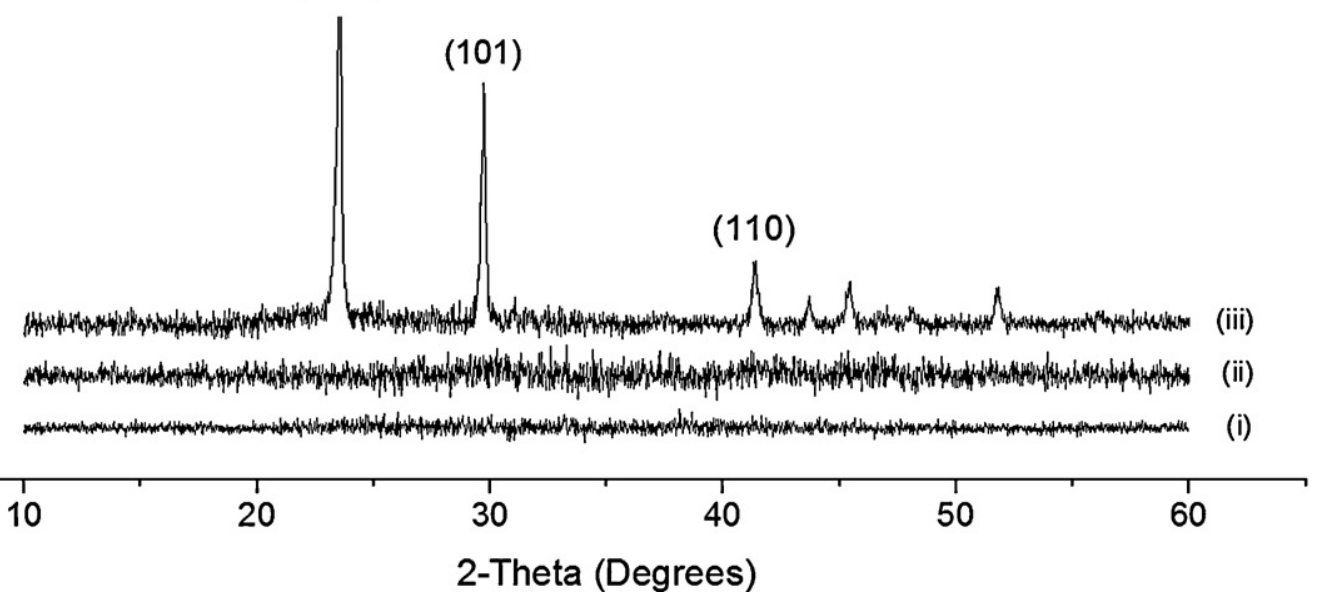

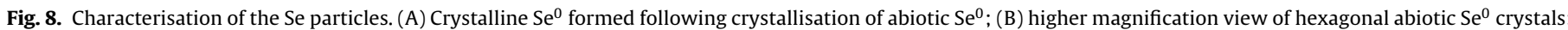

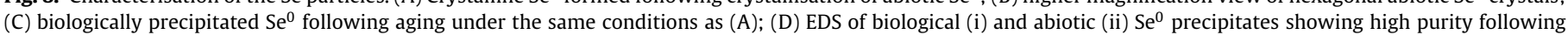

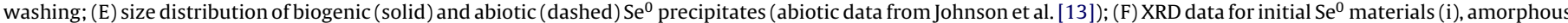
biogenic $\mathrm{Se}^{0}$ after 58 days, hexagonal crystalline abiotic $\mathrm{Se}^{0}$ after 53 days (iii). 


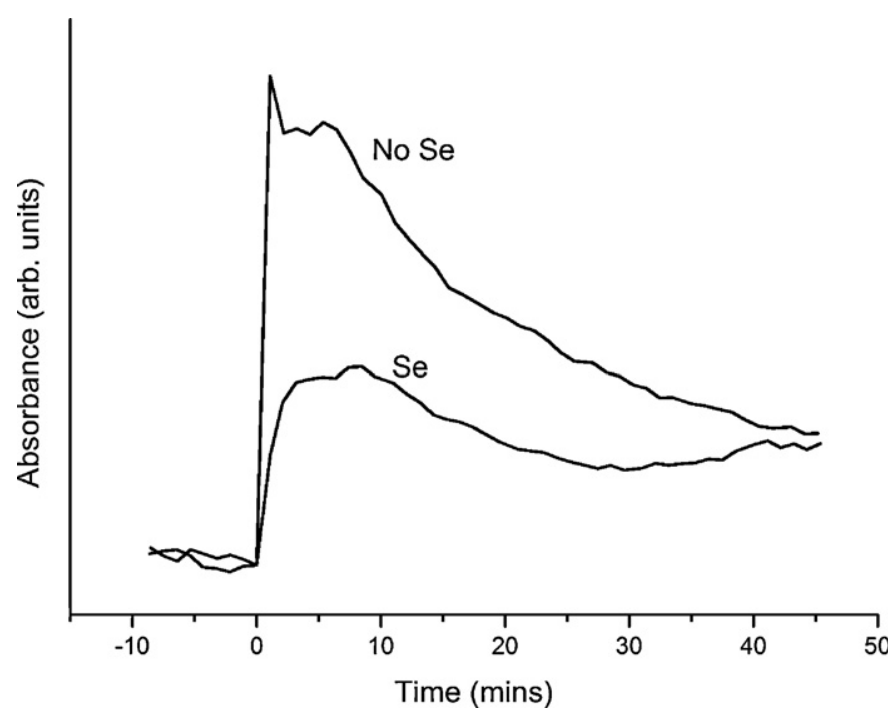

Fig. 9. CVAAS spectra for $\mathrm{Hg}$ concentration of gas phase with (Se) and without (No $\mathrm{Se}$ ) Se-laden membrane filters, showing the absorption of $\mathrm{Hg}_{\mathrm{v}}^{0}$ by $\alpha-\mathrm{Se}^{0}$ is immediate and decreases in efficiency over time.

emission (a decrease of $78 \%$ in peak intensity), and shows an overall decrease of $47 \%$ in $\mathrm{Hg}$ emission in the first $40 \mathrm{~min}$. The extent of $\mathrm{Hg}$ capture decreases over time until $\mathrm{Hg}$ levels approach those of the system without biogenic $\mathrm{Se}^{0}$.

Experiments comparing biogenic and abiotic $\mathrm{Se}^{0}$-containing membrane filters at varying gas flow rates and reaction times using a $10 \mathrm{ppm} \mathrm{Hg}$ source show a strong correlation between the $\mathrm{Hg}$ sequestered and flow rate (Fig. 10), with a maximum $\mathrm{Hg}^{0}$ sequestration of $3.4 \mathrm{mg} \mathrm{m}^{-2}$ for biogenic $\mathrm{Se}^{0}$ at $10 \mathrm{ml} \mathrm{min}^{-1}$, nearly quadruple that of $\mathrm{Hg}^{0}$ sequestered at a flow rate of $50 \mathrm{ml} \mathrm{min}{ }^{-1}$. Abiotic $\alpha-\mathrm{Se}^{0}$ tested under the same conditions was capable of sequestering up to $7.7 \mathrm{mg} \mathrm{m}^{-2}$ of $\mathrm{Hg}^{0}$ at $25 \mathrm{ml} \mathrm{min}^{-1}$, more than four times that of biogenic $\mathrm{Se}^{0}$.

\subsubsection{Sealed environment experiments}

Biogenic $\alpha-\mathrm{Se}^{0}$ was exposed to a range of $\mathrm{HgCl}_{2}$ concentrations between $10 \mathrm{ppb}$ and $10 \mathrm{ppm}$ with $\mathrm{SnCl}_{2}$ at a 1:100 $\mathrm{Hg}: \mathrm{Sn}$ ratio, and an increasing trend of $\mathrm{Hg}_{\mathrm{v}}^{0}$ absorption was noted (Fig. 10C), suggesting that the saturation limit of the biogenic $\mathrm{Se}^{0}$-containing membrane filters was not reached. The maximum $\mathrm{Hg}^{0}$ absorption of $2.2 \mathrm{mg} \mathrm{m}^{-2}$ (equivalent to $2.1 \% \mathrm{Hg}$ by mass of Se), occurred at $10 \mathrm{ppm} \mathrm{HgCl}_{2}$ and represented only $10 \%$ of the maximum $\mathrm{Hg} / \mathrm{Se}$ mass ratio found by Johnson et al. [13]. Abiotic $\mathrm{Se}^{0}$-containing membrane filters were able to capture $>4 \mathrm{mg} \mathrm{Hg}^{0} \mathrm{~m}^{-2}$, double the capacity of biogenic $\mathrm{Se}^{0}$.

Stock solutions of abiotic $\alpha-\mathrm{Se}^{0}$ were seen to change colour from red to black. XRD analysis showed the crystallisation of amorphous $\alpha-\mathrm{Se}^{0}$ to hexagonal Se ${ }^{0}$ (ICDD PDF Card No. 00-006-0362), whereas biological $\mathrm{Se}^{0}$ remained stable in suspension for over a year following synthesis (Fig. 8F). Similarly, a colour change was noted in the abiotic $\mathrm{Se}^{0}$ impregnated membrane filters exposed to $10 \mathrm{ppm} \mathrm{Hg}$, and subsequent SEM analyses (Fig. 8A and B) show that crystallisation of the dried $\mathrm{Se}^{0}$ powders had occurred. EDS analysis confirmed that the crystalline Se was pure Se with no $\mathrm{Hg}$, indicating recrystallisation of Se rather than neocrystallisation of an HgSe phase (Fig. 8D). Biologically precipitated $\alpha-\mathrm{Se}^{0}$ on the impregnated filters did not change (Fig. 8C).

Johnson et al. [13] highlighted the effect of the protein bovine serum albumin (BSA) on $\mathrm{Se}^{0}$ powders; $\mathrm{Hg}^{0}$ capture was hindered relative to $\mathrm{Se}^{0}$ synthesised without $\mathrm{BSA}$, despite a large increase in the available surface area. This was attributed to surface passivation by BSA, reducing the density of available reactive sites on the $\mathrm{Se}^{0}$ particle surface. Results published by Pearce et al. [14] demonstrate the presence of surface-associated proteins on $\mathrm{Se}^{0}$ produced by G. sulfurreducens, and work published by Prakash et al. [27] show that efforts to remove the biological coatings on bacterially precipitated $\mathrm{Se}^{0}$ resulted in the formation of similar hexagonal form seen for abiotic $\mathrm{Se}^{0}$ (Fig. 8A). Similar organic coatings have also recently been characterised by $\mathrm{C}_{60}$ TOF-SIMS on other complimentary bionanomaterials synthesised by G. sulfurreducens [28]. It is likely this surface-bound bacterially derived organic layer is increasing the

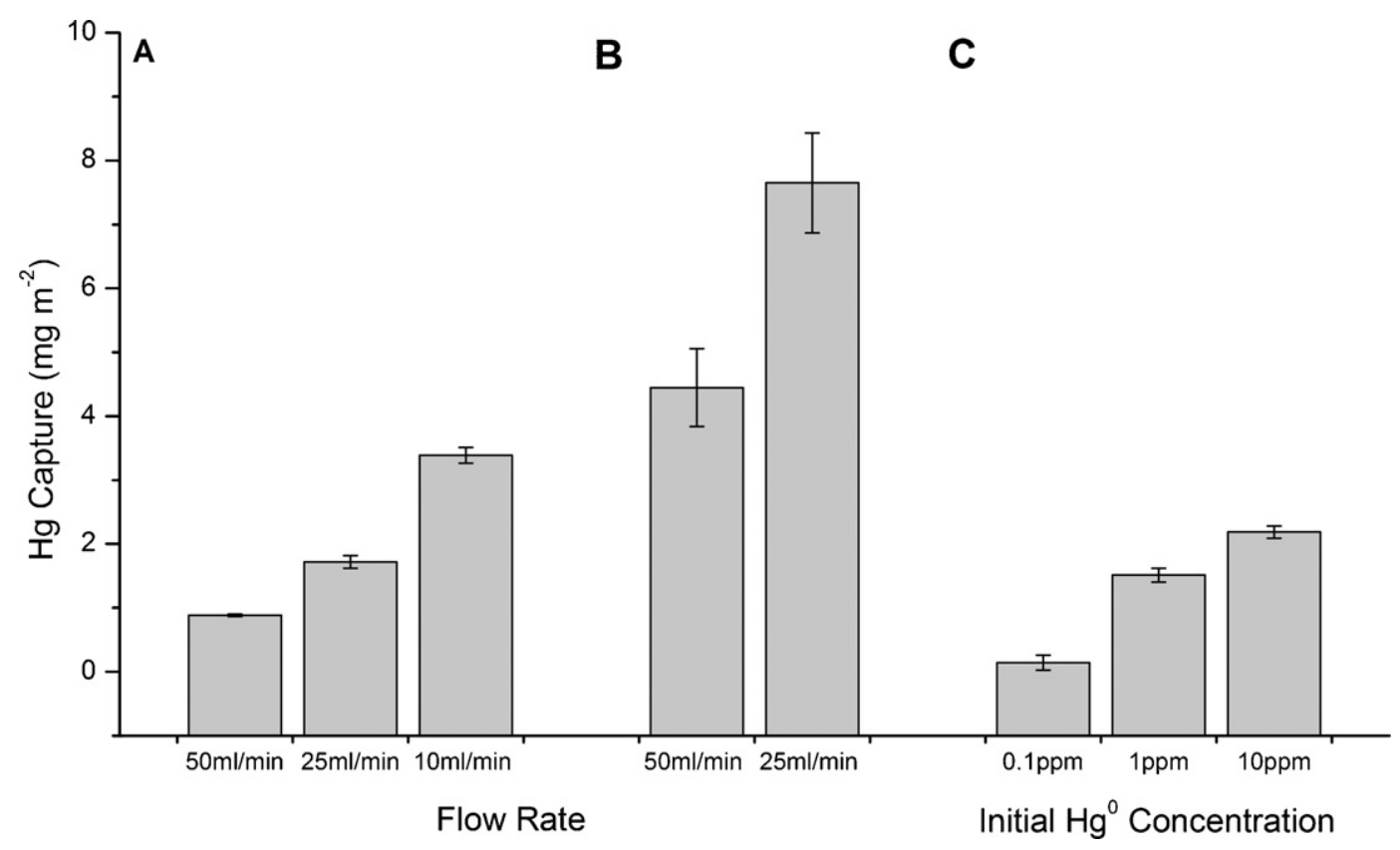

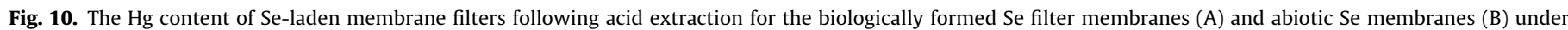
varying carrier gas flow rates. (C) The Hg concentration of biological Se membrane filters under sealed conditions. 


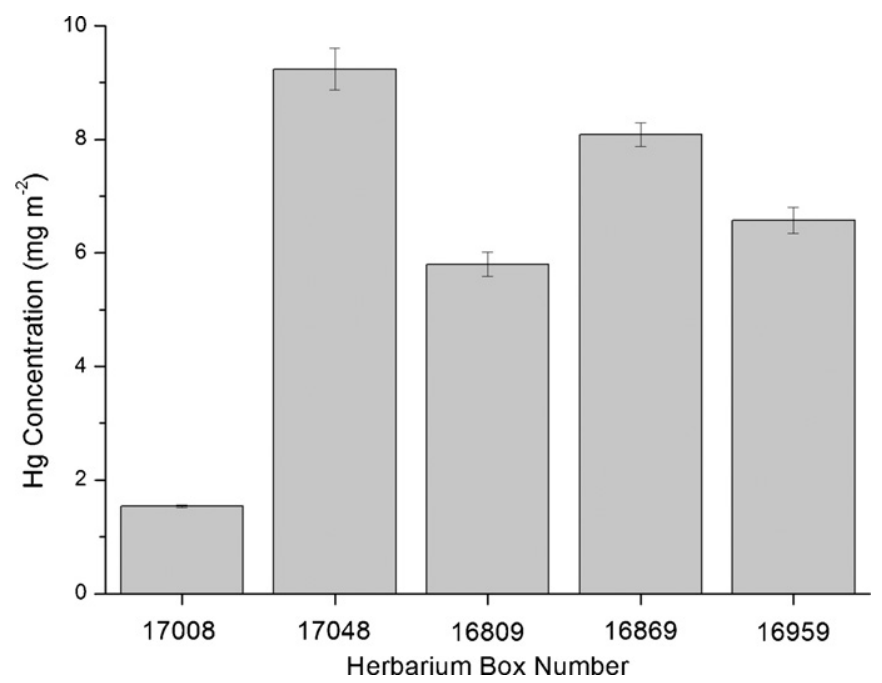

Fig. 11. $\mathrm{Hg}$ concentration of biogenic $\mathrm{Se}^{0}$ filters following acid digestion and ICP analysis. Up to $9 \mathrm{mg} \mathrm{m}^{-2} \mathrm{Hg}$ was shown to be sequestered.

stability of the $\mathrm{Se}^{0}$ particles and passivating the surface, thus reducing $\mathrm{Hg}_{\mathrm{v}}^{0}$ sequestration $[14,18,27]$.

Despite the $50 \%$ reduction in initial $\mathrm{Hg}_{\mathrm{v}}^{0}$ sequestration capacity, the long term instability of the abiotic $\mathrm{Se}^{0}$ may render this material unsuitable for application in long term capture of $\mathrm{Hg}_{\mathrm{v}}^{0}$ emission from museum specimens. Also, as bacterially precipitated $\mathrm{Se}^{0}$ is a by-product of biological selenium treatment to remove selenate and selenite from contaminated natural waters and anthropogenic waste streams [15], the more stable bacterially precipitated $\mathrm{Se}^{0}$ was used for further in situ experimentation to potentially link bioremediation strategies with production of functional bionanominerals.

\subsubsection{In situ experiments}

Biogenic $\mathrm{Se}^{0}$-containing membrane filters were placed in five boxes of the European collection with $\mathrm{Hg}_{\mathrm{v}}^{0}$ concentrations greater than $25 \mu \mathrm{g} \mathrm{m}^{-3}$ (Fig. 2) and left for 4 weeks. The effect of the biogenic $\mathrm{Se}^{0}$-containing membrane filters on the concentration of $\mathrm{Hg}_{\mathrm{v}}^{0}$ in the air within herbarium specimen boxes could not be determined due to the changes in ambient air temperature during the course of the in situ experiment; a temperature increase from $19^{\circ} \mathrm{C}$ to $24^{\circ} \mathrm{C}$ occurred during the 4 weeks, leading to in an increase in $\mathrm{Hg}_{\mathrm{v}}^{0}$ release as previously observed by Oyarzun et al. [8]. An increase from $42 \mu \mathrm{g} \mathrm{m}^{-3} \mathrm{Hg}_{\mathrm{v}}^{0}$ to $90 \mu \mathrm{g} \mathrm{m}^{-3}$ in one specimen box was seen. SEM images of the biogenic $\mathrm{Se}^{0}$ before and after exposure to $\mathrm{Hg}_{\mathrm{v}}^{0}$ in the specimen boxes are shown in Fig. 7. The initial form of the $\alpha-\mathrm{Se}^{0}$ is as clearly defined spheres with smooth surfaces with particle sizes ranging from 35 to $680 \mathrm{~nm}$ (Figs. 7A and 8E). Following 4 weeks in $\mathrm{Hg}$ contaminated herbarium boxes, there was a morphological change of some spheres to a rough, textured surface (Fig. 7B and C). EDS spectra of remaining smooth and rough spheres showed that smooth particles contained little $\mathrm{Hg}$, whereas the rough textured particles show a significant $\mathrm{Hg}$ concentration (Fig. 7Dii). EDS analysis showed that these particles were composed of $\mathrm{Hg}$ and $\mathrm{Se}$ (31-33\% $\mathrm{Hg}$ by mass). As pure $\mathrm{HgSe}$ is $\sim 72 \% \mathrm{Hg}$ by mass, these results suggest that there is a significant surface coating of an $\mathrm{HgSe}$ phase.

Following exposure of biogenic $\mathrm{Se}^{0}$ to $\mathrm{Hg}_{\mathrm{v}}^{0}$ in the specimen boxes, a sample was analysed using XAS at the $\mathrm{Hg} \mathrm{L}_{3}$-edge (Fig. 6C). Linear combination fitting of the recorded XANES profiles against published standards suggests the presence of $\mathrm{HgSe}$, concurrent with EDS findings. An IPD value of $7.47 \mathrm{eV}$ was determined from the 1 st derivation of the XANES spectra, which differs from published
HgSe IPD values [23], likely as a result of the low $\mathrm{Hg}$ concentrations in the sample, resulting in a high signal:noise ratio (Fig. 6C, inset).

Acid digestion of the biogenic $\mathrm{Se}^{0}$-containing membrane filters in aqua regia was carried out to determine total $\mathrm{Hg}$ concentrations (Fig. 11). All membrane filters tested showed $\mathrm{Hg}$ concentrations in the range $0.02-0.19 \mu \mathrm{g} \mathrm{Hg}$ per $\mu \mathrm{g}$ Se, corresponding to the sequestration of up to $19 \% \mathrm{Hg}$ by mass, which is comparable to the sequestration results obtained for abiotic $\mathrm{Se}^{0}$ by Johnson et al. [13].

The normalised concentration of $\mathrm{Hg}_{\mathrm{v}}^{0}$ sequestered by the biogenic $\mathrm{Se}^{0}$-containing membrane filters shows a linear correlation with the $\mathrm{Hg}_{\mathrm{v}}^{0}$ concentration of the air within the herbarium specimen boxes.

\section{Conclusion}

Measurement of $\mathrm{Hg}$ concentrations in the Manchester museum herbarium has identified the presence of $\mathrm{Hg}_{\mathrm{v}}^{0}$ both within wellsealed specimen boxes and in the air of the herbarium workspaces. The concentration of $\mathrm{Hg}_{\mathrm{v}}^{0}$ in workspaces did not exceed $1.7 \mu \mathrm{g} \mathrm{m}^{-3}$, which is well below the lowest advised workplace mercury exposure limit of $25 \mu \mathrm{g} \mathrm{m}^{-3}$. The $\mathrm{Hg}_{\mathrm{v}}^{0}$ content observed within specimen boxes was variable and sometimes very high, increasing from $43 \mu \mathrm{g} \mathrm{m}^{-3}$ at $19^{\circ} \mathrm{C}$ to $90 \mu \mathrm{g} \mathrm{m}^{-3}$ at $24^{\circ} \mathrm{C}$ in one box. The construction of the specimen boxes is an advantage as it prohibits the release of $\mathrm{Hg}_{\mathrm{v}}^{0}$ into the workspace, but allows the build up of significant concentrations of $\mathrm{Hg}_{\mathrm{v}}^{0}$ within boxes, which is released when materials are accessed. $\mathrm{Hg}$-contamination of specimens is variable between collections, within collections and even within specimens stored in the same box. $\mathrm{Hg}$ is found on specimens predominantly as metacinnabar. However, indications of a surface coating of $\mathrm{HgO}$ and the presence of $\mathrm{HgCl}_{2}$ suggest that the form of $\mathrm{Hg}$ in this system is affected by a number of factors including biological activity, oxidation and original $\mathrm{Hg}$ concentration. Significant quantities of $\mathrm{Hg}(2.5 \mathrm{wt} \%)$ were found in some specimens. $\mathrm{Hg}^{0}$ was not found to be directly associated with the specimens, but a strong correlation between temperature and release of $\mathrm{Hg}_{\mathrm{v}}^{0}$ was observed.

Biogenic $\alpha-\mathrm{Se}^{0}$ efficiently sequesters $\mathrm{Hg}_{\mathrm{v}}^{0}$, with a $47 \%$ initial reduction in $\mathrm{Hg}$ emission. Contact time between the $\mathrm{Hg}_{\mathrm{v}}^{0}$ and the biogenic $\mathrm{Se}^{0}$ nanoparticles has a significant effect on the reaction rate, with the biogenic $\mathrm{Se}^{0}$ capturing $\mathrm{Hg}^{0}$ more effectively at lower gas flow rates, similar to the conditions of low level, continuous $\mathrm{Hg}_{\mathrm{v}}^{0}$ release expected in the sealed specimen boxes. The sequestration of the $\mathrm{Hg}^{0}$ as a stable layer of $\mathrm{HgSe}$ on the surface of the nanoparticles represents a safe option to limit the release of $\mathrm{Hg}_{\mathrm{v}}^{0}$ into the air. The observed absorption capacity of up to $20 \% \mathrm{Hg}$ by mass compares favourably with that observed for abiotically synthesised $\alpha-\mathrm{Se}^{0}$. A major advantage of biogenic $\alpha-\mathrm{Se}^{0}$ over abiotic $\alpha-\mathrm{Se}^{0}$ is the improvement in long term stability, which offsets the initial low reaction rates with improved longer term performance. Amorphous elemental red Se nanospheres produced both biogenically and abiotically represent a promising new way to capture $\mathrm{Hg}_{\mathrm{v}}^{0}$ released from $\mathrm{Hg}$ - contaminated herbarium specimens. The potential to use biogenic Se nanospheres, formed as a by product of biological treatment of selenium contaminated wastewater, also provides an opportunity to link bioremediation strategies with production of new nanomaterials for environmental protection.

\section{Acknowledgements}

The authors would like to thank Paul Lythgoe for ICP-MS/AES and CVAAS analysis, Cath Davies for acid digestions, Dr Paul Wincott for XPS, Dr John Waters for XRD, Dr John Charnock for advice on XAS and Dr Melanie Taylor. This research was supported by the Natural Environment Research Council (NERC), UK. 


\section{References}

[1] S.H. Clark, Preservation of herbarium specimens - an archive conservators approach, Taxon 35 (1986) 675-682.

[2] V. Purewal, B. Colston, S. Rohrs, Developing a simple screening method for the identification of historic biocide residues on herbarium material in museum collections, X-ray Spectrom. 37 (2008) 137-141.

[3] P.T. Palmer, M. Martin, G. Wentworth, N. Caldararo, L. Davis, S. Kane, D. Hostler Analysis of pesticide residues on museum objects repatriated to the Hupa Tribe of California, Environ. Sci. Technol. 37 (2003) 1083-1088.

[4] D. Briggs, P.D. Sell, M. Block, R.D. Ions, Mercury-vapor - a health-hazard in herbaria, New Phytol. 94 (1983) 453-457.

[5] J. Sirois, Analysis of mercury compounds on herbarium sheet test specimens, in: Analytical Research Laboratory Report No. 3708, Canadian Conservation Institute, Ottawa, 1998.

[6] C. Hawks, K. Makos, D. Bell, P.E. Wambach, G.E. Burroughs, An inexpensive method to test for mercury vapor in herbarium cabinets, Taxon 53 (2004) 783-790.

[7] P.J. Sirois, The analysis of museum objects for the presence of arsenic and mercury: non-destructive analysis and sample analysis, Collect. Forum 16 (2001) 65-75.

[8] R. Oyarzun, P. Higueras, J.M. Esbri, J. Pizarro, Mercury in air and plant specimens in herbaria: a pilot study at the MAF Herbarium in Madrid (Spain), Sci. Tota Environ. 387 (2007) 346-352.

[9] M. Kataeva, N. Panichev, A.E. van Wyk, Monitoring mercury in two South African herbaria, Sci. Total Environ. 407 (2009) 1211-1217

[10] J. Sirois, K. Helwig, Analysis of darkened areas on mounting papers used in historical herbarium specimens, in: Analytical Research Laboratory Report No. 3599, Canadian Conservation Institute, Ottawa, 1996.

[11] T.A. Baughman, Elemental mercury spills, Environ. Health Perspec. 114 (2006) $147-152$.

[12] T.M. Roane, L.J. Snelling, Bacterial removal of mercury from museum materials: a new remediation technology? in: A.E. Charola, R.J. Koestler (Eds.), Pesticide Mitigation in Museum Collections: Science in Conservation. Proceedings from the MCI Workshop Series, Smithsonian Institution Scholarly Press, 2009, pp. 29-34.

[13] N.C. Johnson, S. Manchester, L. Sarin, Y.M. Gao, I. Kulaots, R.H. Hurt, Mercury vapor release from broken compact fluorescent lamps and in situ capture by new nanomaterial sorbents Environ. Sci. Technol. 42 (2008) 5772-5778.

[14] C. Pearce, R.A.D. Pattrick, N. Law, J.M. Charnock, V.S. Coker, J.W. Fellowes, R.S. Oremland, J.R. Lloyd, Investigating different mechanisms for biogenic selenite transformations: Geobacter sulfurreducens, Shewanella oneidensis and Veillonella atypica, Environ. Technol. 30 (2009) 1313-1326.
[15] M. Lenz, E.D. Van Hullebusch, G. Hommes, P.F.X. Corvini, P.N.L. Lens, Selenate removal in methanogenic and sulfate-reducing upflow anaerobic sludge bed reactors, Water Res. 42 (2008) 2184-2194.

[16] M. Lenz, P.N.L. Lens, The essential toxin: the changing perception of selenium in environmental sciences, Sci. Total Environ. 407 (2009) 3620-3633.

[17] L.E. Macaskie, I.P. Mikheenko, P. Yong, K. Deplanche, A.J. Murray, M. PatersonBeedle, V.S. Coker, C.I. Pearce, R. Cutting, R.A.D. Pattrick, D. Vaughan, G. van der Laan, J.R. Lloyd, Today's wastes, tomorrow's materials for environmental protection, Hydrometallurgy 104 (2010) 483-487.

[18] J. Kessi, M. Ramuz, E. Wehrli, M. Spycher, R. Bachofen, Reduction of selenite and detoxification of elemental selenium by the phototrophic bacterium Rhodospirillum rubrum, Appl. Environ. Microbiol. 65 (1999) 4734-4740.

[19] R.S. Oremland, M.J. Herbel, J.S. Blum, S. Langley, T.J. Beveridge, P.M. Ajayan, T. Sutto, A.V. Ellis, S. Curran, Structural and spectral features of selenium nanospheres produced by se-respiring bacteria, Appl. Environ. Microbiol. 70 (2004) 52-60.

[20] J.R. Lloyd, C. Leang, A.L.H. Myerson, M.V. Coppi, S. Cuifo, B. Methe, S.J. Sandler, D.R. Lovley, Biochemical and genetic characterization of PpcA, a periplasmic c-type cytochrome in Geobacter sulfurreducens, J. Biochem. 369(2003)153-161.

[21] E. Yamada, T. Yamada, M. Sato, Determination of trace mercury in the environmental water containing iodide by using cold-vapor atomic-absorption spectrometry, Anal. Sci. 8 (1992) 863-868.

[22] L.B. Zhao, G.T. Rochelle, Hg absorption in aqueous permanganate, AIChE J. 42 (1996) 3559-3562.

[23] F.E. Huggins, N. Yap, G.P. Huffman, C.L. Senior, XAFS characterization of mercury captured from combustion gases on sorbents at low temperatures, Fuel Process. Technol. 82 (2003) 167-196.

[24] J.F. Moulder, W.F. Stickle, P.E. Sobol, K.D. Bomben, Handbook of X-ray Photoelectron Spectroscopy: A Reference Book of Standard Spectra for Identification and Interpretation of XPS Data, Perkin-Elmer Corp. (1992).

[25] F.E. Huggins, G.P. Huffman, G.E. Dunham, C.L. Senior, XAFS examination of mercury sorption on three activated carbons, Energy Fuels 13 (1999) 114-121.

[26] G.N. George, S.P. Singh, R.C. Prince, I.J. Pickering, Chemical forms of mercury and selenium in fish following digestion with simulated gastric fluid, Chem. Res. Toxicol. 21 (2008) 2106-2110.

[27] N.T. Prakash, N. Sharma, R. Prakash, K.K. Raina, J. Fellowes, C.I. Pearce, J.R. Lloyd, R.A.D. Pattrick, Aerobic microbial manufacture of nanoscale selenium: exploiting nature's bio-nanomineralization potential, Biotechnol. Lett. (2009).

[28] V.S. Coker, J.A. Bennett, N.D. Telling, T. Henkel, J.M. Charnock, G. van der Laan, R.A.D. Pattrick, C.I. Pearce, R.S. Cutting, I.J. Shannon, J. Wood, E. Arenholz, I.C. Lyon, J.R. Lloyd, Microbial engineering of nanoheterostructures: biological synthesis of a magnetically recoverable palladium nanocatalyst, ACS Nano 4(2010) 2577-2584. 